\title{
ANALISIS PENGARUH KUALITAS PELAYANAN \\ TERHADAP KEPUASAN MAHASISWA \\ UNIVERSITAS BUANA PERJUANGAN KARAWANG
}

Wanta

Fakultas Bisnis dan Ilmu Sosial Universitas Buana Perjuangan Karawang

Email :wanta@ubpkarawang.ac.id; HP : 081286968419

\begin{abstract}
ABSTRAK
Penelitian ini bertujuan untuk mengetahui pengaruh kualitas pelayanan terhadap kepuasan mahasiswa Universitas Buana Perjuangan Karawang.

Penelitian ini menggunakan metode koefisien korelasi yang bertujuan untuk mengetahui tingkat hubungan antar variabel. Nilai korelasi secara parsial antara fasilitas akademik dengan kepuasan mahasiswa sebesar 0,503, mempunyai tingkat hubungan sedang dan positif atau searah. Nilai korelasi antara fasilitas akademik dengan kepuasan mahasiswa dengan variabel kontrol layanan akademik, praktikum dan proses akademik sebesar 0,072, mempunyai tingkat hubungan sangat rendah dan positif atau searah. Nilai korelasi secara parsial antara layanan akademik dengan kepuasan mahasiswa sebesar 0,655, mempunyai tingkat hubungan kuat dan positif atau searah. Nilai korelasi antara layanan akademik dengan kepuasan mahasiswa dengan variabel kontrol fasilitas akademik, praktikum dan proses akademik sebesar 0,307, mempunyai tingkat hubungan rendah dan positif atau searah. Nilai korelasi antara praktikum dengan kepuasan mahasiswa secara parsial sebesar 0,625, mempunyai tingkat hubungan kuat dan positif atau searah. Nilai korelasi antara praktikum dengan kepuasan mahasiswa dengan variabel kontrol fasilitas akademik, layanan akademik dan proses akademik sebesar 0,192, mempunyai tingkat hubungan sangat rendah dan positif atau searah. Nilai korelasi antara proses akademik dengan kepuasan mahasiswa secara parsial sebesar 0,583, mempunyai tingkat hubungan sedang dan positif atau searah. nilai korelasi antara proses akademik dengan kepuasan mahasiswa dengan variabel kontrol fasilitas akademik, layanan akademik dan praktikum sebesar 0,205, mempunyai tingkat hubungan rendah dan positif atau searah.

Hasil analisis regresi analisis kualitas pelayanan terhadap kepuasan mahasiswa diperoleh nilai koefisien korelasi $(\mathrm{R})$ sebesar 0,724 atau $\mathrm{R}>0$, artinya bahwa terdapat hubungan kuat $(0,600-0,799=$ kuat $)$ antara kualitas pelayanan (fasilitas akademik, layanan akademik, praktikum dan proses akademik) dengan kepuasan mahasiswa. Nilai koefisien
\end{abstract}


Analisis Pengaruh Kualitas Pelayanan Terhadap Kepuasan Mahasiswa Universitas Buana Perjuangan Karawang

determinasi ( $\mathrm{R}$ Square atau $\mathrm{R}^{2}$ ) sebesar 0,524 atau 52,40\%, Nilai tersebut menunjukan kemampuan variabel kualitas pelayanan (fasilitas akademik, layanan akademik, praktikum dan proses akademik) menjelaskan variansi pada variabel kepuasan mahasiswa sebesar $52,40 \%$ dan sisanya sebesar 47,60\% dipengaruhi oleh faktor lain (e) yang tidak diikutsertakan dalam penelitian ini. Faktor lain tersebut seperti komunikasi, budaya organisasi, prestasi akademik dan lain-lain.

Kata kunci: Kualitas Pelayanan, Kepuasan Mahasiswa 


\section{PENDAHULUAN}

\section{Latar Belakang}

Iklim peningkatan kualitas dunia pendidikan tinggi di Indonesia saat ini sedang digalakan. Perguruan Tinggi di Indonesia baik yang berstatus negeri maupun swasta tidak hanya dipacu untuk mampu bersaing pada tingkat lokal, tetapi juga dipacu untuk mampu bersaing di tingkat nasional bahkan internasional. Berdasarkan data statistik Pendidikan Perguruan Tinggi Kemendikbud Tahun 2016 menyebutkan Akademi berjumlah 1.109, Politeknik berjumlah 247, Sekolah Tinggi berjumlah 2.440, Institut berjumlah 144 dan Universitas berjumlah 577. Meningkatnya kuantitas perguruan tinggi ini menuntut masingmasing lembaga pendidikan harus memperhatikan mutu pendidikan dan kelembagaan sehingga mampu serta unggul dalam mencapai peningkatan kualitas.

Kualitas suatu perguruan tinggi sangat ditentukan oleh mutu pelayanan yang diberikan, dimana pelayanan yang bermutu dapat diindetifikasi melalui kepuasan mahasiswa. Bagi sebuah perguruan tinggi kepuasan layanan lebih diorientasikan kepada mahasiswa karena mahasiswa merupakan pelanggan primer dari perguruan tinggi.

Kepuasan mahasiswa ditujukan dengan adanya keloyalan mahasiswa pada perguruan tinggi dan mahasiswa akan menceritakan mengenai layanan akademik yang memuaskan kepada orang lain. Kepuasan menurut Pakar Day (Tjiptono, 2004) bahwa kepuasan atau ketidakpuasan adalah respon pelanggan terhadap evaluasi ketidaksesuaian / diskonfirmasi yang dirasakan antara harapan sebelumnya dan kinerja aktual produk yang diarasakan setelah pemakaiannya. Tingkat kepuasan mahasiswa terhadap jasa pelayanan pendidikan dapat diketahui dengan cara membandingkan anatara harapan dengan kenyataan yang mahasiswa rasakan. Wadwa dan Radja (2006) mengemukakan bahwa kepuasan mahasiswa akan layanan yang diterimanya dilihat dari kesesuaian anatara harapan dan kinerja layanan yang diterimanya.

Universitas Buana Perjuangan Karawang (UBP Karawang) sebagai salah satu lembaga pendidikan tinggi harus menerapkan konsep mengutamakan kepuasan mahasiswa sebagai pelanggan dengan memberikan pelayanan terbaik. Kepuasan mahasiswa merupakan misi yang harus diwujudkan apabila suatu lembaga pendidikan ingin diterima oleh masyarakat serta dapat terus eksis dan berkembang di tengah-tengah dukungan masyarakat. Bentuk pelayanan yang diterima oleh mahasiswa di perguruan tinggi dapat mencakup pelayanan kegiatan akademik, kemahasiswaan dan administrasi. 


\section{Perumusan Masalah}

Dari uraian pada latar belakang di atas maka dapat dirumuskan permasalahan penelitian ini sebagai berikut:

1. Bagaimana pengaruh fasilitas akademik/perkuliahan terhadap kepuasan mahasiswa Universitas Buana Perjuangan Karawang?

2. Bagaimana pengaruh layanan akademik/perkuliahan terhadap kepuasan mahasiswa Universitas Buana Perjuangan Karawang?

3. Bagaimana pengaruh praktikum terhadap kepuasan mahasiswa Universitas Buana Perjuangan Karawang?

4. Bagaimana pengaruh proses akademik/perkuliahan terhadap kepuasan mahasiswa Universitas Buana Perjuangan Karawang?

\section{A. KAJIAN PUSTAKA}

\section{Kualitas Pelayanan}

Kata kualitas memiliki banyak definisi yang berbeda, dan bervariasi dari yang konvensional sampai yang lebih strategik. Definisi konvensional dari kualitas biasanya mengambarkan karakteristik langsung dari suatu produk seperti : performansi (performance), keadaan (reability), mudah dalam penggunaan (case of use), estetika (esthetics), dan sebagainya. Sedangkan definisi strategik menyatakan bahwa kualitas adalah segala sesuatu yang mampu memenuhi keinginan atau kebutuhan pelanggan (meeting the need of costomers).

Modernitas dengan kemajuan teknologi akan mengakibatkan persaingan yang sangat ketat untuk memperoleh dan mempertahankan pelanggan. Kualitas pelayanan menjadi suatu keharusan yang harus dilakukan perguruan tinggi agar mampu bertahan dan tetap mendapat kepercayaan pelanggan. Keberhasilan perusahaan dalam memberikan pelayanan yang berkualitas dapat ditentukan dengan pendekatan service quality yang telah dikembangkan oleh Parasuraman, Berry dan Zenthaml (dalam Lupiyoadi, 2006).

Definisi mutu jasa berpusat pada pemenuhan kebutuhan dan keinginan pelanggan serta ketepatan penyampaian untuk mengimbangi harapan pelanggan. Menurut Wyckof (dalam Wisnalmawati, 2005) kualitas jasa adalah tingkat keunggulan yang diharapkan dan pengendalian atas tingkat keunggulan untuk memenuhi keinginan pelanggan. Apabila jasa yang diterima sesuai dengan yang diharapkan, maka kualitas jasa dipersepsikan baik dan memuaskan. Jika jasa yang diterima melampaui harapan pelanggan, maka kualitas jasa 
dipersepsikan ideal. Sebaliknya jika jasa yang diterima lebih rendah dari pada yang diharapkan, maka kualitas jasa dianggap buruk (Tjiptono, 2005).

Mengacu pada pengertian kualitas layanan tersebut maka konsep kualitas layanan adalah suatu daya tanggap dan realitas dari jasa yang diberikan perusahaan. Kualitas pelayanan harus dimulai dari kebutuhan pelanggan dan berakhir pada persepsi pelanggan (Kotler, 1997) dalam Wisnalmawati (2005). Hal ini berarti bahwa kualitas yang baik bukanlah berdasarkan persepsi penyediaan jasa, melainkan berdasarkan persepsi pelanggan.

Terdapat lima dimensi kualitas pelayanan menurut Parasuraman dalam Lupiyoadi (2006), yaitu :

1. Tangibles, atau bukti fisik yaitu kemampuan perusahaan dalam menunjukkan eksistensinya kepada pihak eksternal.

2. Reliability, atau kehandalan yaitu kemampuan perusahaan untuk memberikan pelayanan sesuai yang dijanjikan secara akurat dan terpercaya.

3. Responsiveness, atau ketanggapan yaitu suatu kemauan untuk membantu dan memberikan pelayanan yang cepat dan tepat kepada pelanggan dengan penyampaian informasi yang jelas.

4. Assurance, atau jaminan dan kepastian yaitu pengetahuan, kesopansantunan, dan kemampuan para pegawai perusahaan untuk menumbuhkan rasa percaya para pelanggan kepada perusahaan. Terdiri dari beberapa komponen antara lain komunikasi, kredibilitas, keamanan, kompetensi dan sopan santun.

5. Empathy, yaitu memberikan perhatian yang tulus dan bersifat individual atau pribadi yang diberikan kepada para pelanggan dengan berupaya memahami keinginan pelanggan.

\section{Kepuasan Mahasiswa}

Menurut Kotler, kepuasan adalah tingkat perasaan seseorang setelah membandingkan kinerja atau hasil yang dia rasakan dibandingkan dengan harapannya (Kotler dkk, 2002). Sedangkan Tse dan Wilton (1988) dalam Lupiyoadi (2004) kepuasan atau ketidakpuasan pelanggan adalah respon pelanggan terhadap evaluasi ketidaksesuaian (disconfirmation) yang dirasakan antara harapan sebelumnya dan kinerja aktual produk yang dirasakan setelah pemakaiannya.

Kepuasan pelanggan merupakan respons pelanggan terhadap ketidaksesuaian antara tingkat kepentingan sebelumnya dan kinerja aktual yang dirasakannya setelah pemakaian 
Analisis Pengaruh Kualitas Pelayanan Terhadap Kepuasan Mahasiswa Universitas Buana Perjuangan Karawang

(Rangkuti, 2002). Kepuasan pelanggan dipengaruhi oleh persepsi kualitas jasa, kualitas produk, harga dan faktor-faktor yang bersifat pribadi serta yang bersifat situasi sesaat.

Fandy Tjiptono, Gregorius Chandra \& Dadi Adriana (2008), mengatakan sampai saat ini kepuasan pelanggan diinterprestasikan dan diteliti berdasarkan 10 teori yang dapat dikelompokan berdasarkan tiga perspektif utama : prespektif psikologi, prespektif ekonomi, presfektif sosiologi. Seperti yang terlihat di bawah ini :

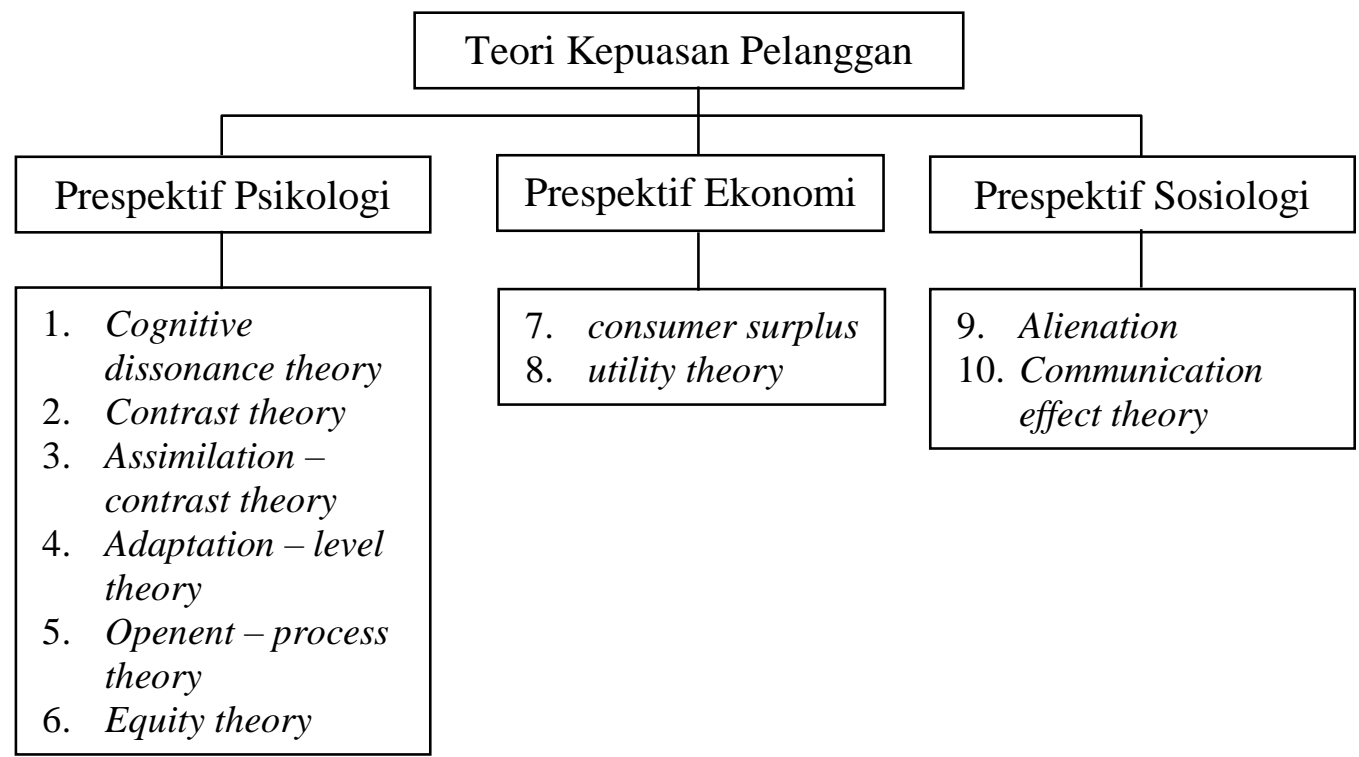

Gambar 2.1 Sepuluh Teori Pokok Kepuasan Pelanggan

\section{Kerangka Berpikir}

Kualitas pelayanan menjadi suatu keharusan yang harus dilakukan perguruan tinggi agar mampu bertahan dan tetap mendapat kepercayaan pelanggan. Keberhasilan perguruan tinggi dalam memberikan pelayanan yang berkualitas dapat ditentukan dengan pendekatan service quality.

Kepuasan mahasiswa banyak dipengaruhi oleh beberapa faktor, salah satunya adalah kualitas pelayanan. Kepuasan adalah tingkat perasaan seseorang setelah membandingkan kinerja atau hasil yang dia rasakan dibandingkan dengan harapannya.

Kerangka berpikir dalam penelitian ini dapat digambarkan sebagai berikut: 


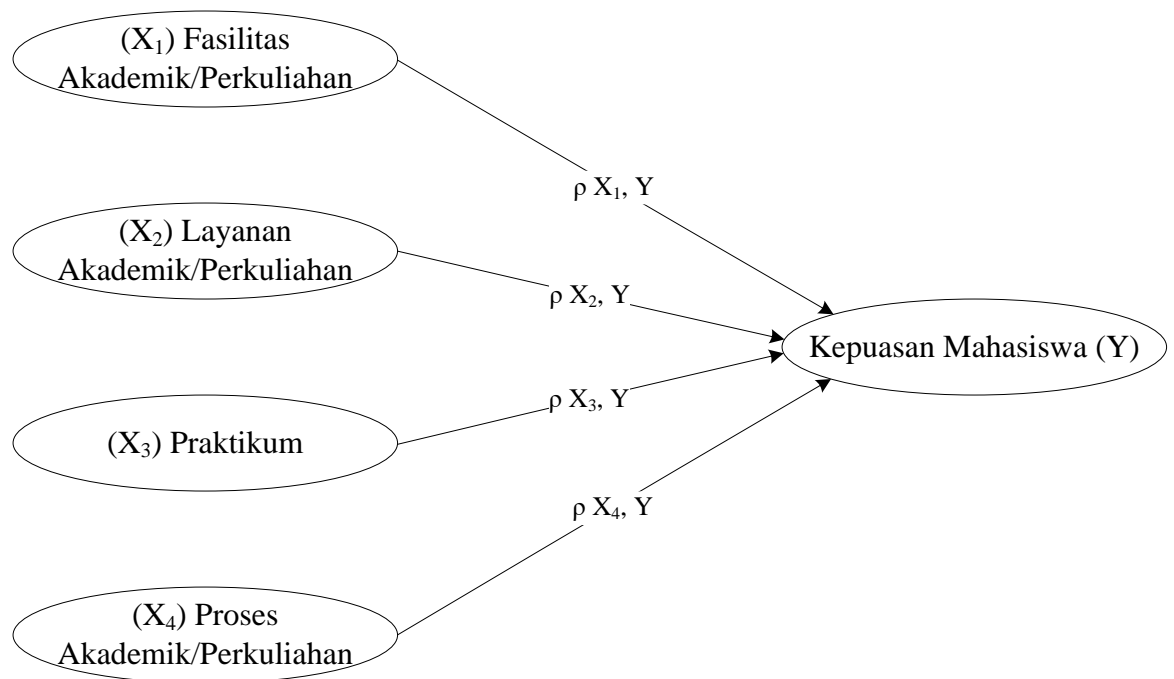

Gambar 1. Kerangka Berpikir Penelitian

\section{Hipotesis}

Hipotesis yang diajukan dalam penelitian ini adalah:

1. $\mathrm{H}_{\mathrm{a} 1}$ : Fasilitas akademik/perkuliahan berpengaruh positif dan signifikan terhadap kepuasan mahasiswa Universitas Buana Perjuangan Karawang

2. $\mathrm{H}_{\mathrm{a} 2}$ : Layanan akademik/perkuliahan berpengaruh positif dan signifikan terhadap kepuasan mahasiswa Universitas Buana Perjuangan Karawang

3. $\mathrm{H}_{\mathrm{a} 3}$ : Praktikum berpengaruh positif dan signifikan terhadap kepuasan mahasiswa Universitas Buana Perjuangan Karawang

4. $\mathrm{H}_{\mathrm{a} 4}$ : Proses akademik/perkuliahan berpengaruh positif dan signifikan terhadap kepuasan mahasiswa Universitas Buana Perjuangan Karawang

\section{B. METODE PENELITIAN}

\section{Desain Penelitian}

Penelitian ini didesain untuk mengetahui pengaruh kualitas pelayanan terhadap kepuasan mahasiswa pada Universitas Buana Perjuangan Karawang. Obyek penelitiannya adalah seluruh mahasiswa (populasi), teknik pengambilan sample dengan menggunakan rumus slovin. Instrument pengumpulan data dengan menggunakan kuesioner yang dibagikan kepada mahasiswa yang telah ditetapkan sebagai sample (responden), didalam kuesioner tersebut berisi pertanyaan-pertanyaan mengenai kualitas pelayanan dan kepuasan mahasiswa, responden dapat memilih salah satu jawaban dari lima alternatif jawaban yang telah disediakan. Kuesioner yang telah diisi kemudian dikumpulkan untuk dilakukan tabulasi data. 
Setelah tabulasi data selesai langkah selanjutnya adalah melakukan adalah melakukan analisis data. Metode analisis data dengan bantuan program aplikasi SPSS (Statistical Product and Service Solutions).

\section{Variabel Penelitian}

Sesuai dengan kerangka berpikir yang telah dijelaskan di atas, maka penentuan variabel dalam penelitian ini adalah:

a. Variabel dependen (terikat) adalah sejumlah gejala dengan berbagai unsur atau faktor didalamnya yang ada ditentukan dan dipengaruhi oleh adanya variabel lain. Dalam penelitian ini yang menjadi variabel dependen yaitu kepuasan mahasiswa.

b. Variabel independen (bebas) adalah sejumlah gejala dengan berbagai unsur atau faktor didalamnya menentukan dan mempengaruhi adanya variabel-variabel yang lain. Dalam penelitian ini yang menjadi variabel independen adalah kualitas pelayanan.

\section{Definisi Operasional Variabel}

Definisi operasional variabel merupakan penjabaran suatu variabel ke dalam indikator-indikator. Dengan adanya definisi operasional pada variabel yang dipilih dan digunakan dalam penelitian maka akan mudah diukur. Variabel tersebut adalah sebagai berikut:

a. Variabel Dependen

Kepuasan mahasiswa. Indikator kepuasan mahasiswa meliputi:

1) Prespektif psikologi

2) Prespektif ekonomi

3) Prespektif sosiologi

b. Variabel Independen

Kualitas pelayanan. Indikator kualitas pelayanan meliputi:

1) Fasilitas akademik/perkuliahan.

2) Layanan akademik/perkuliahan.

3) Praktikum.

4) Proses akademik/perkuliahan. 


\section{Populasi dan Sampel}

Populasi adalah sekelompok orang, kejadian atau segala sesuatu yang mempunyai karakteristik tertentu (Indriantoro dan Bambang, 1999). Populasi dalam penelitian ini adalah mahasiswa Universitas Buana Perjuangan Karawang yaitu sebanyak 2.764 orang. Sampel adalah bagian dari populasi yang karakteristiknya hendak diselidiki dan dianggap bisa mewakili keseluruhan populasi. Sampel adalah bagian dari jumlah dan karakteristik yang dimiliki oleh populasi tersebut (Sugiyono, 2001).

Teknik sampling yang digunakan dalam penelitian ini adalah dengan menggunakan rumus Slovin yang dikutif Sevila dalam buku Husein Umar yaitu:

$$
\begin{aligned}
& \mathrm{n}=\frac{\mathrm{N}}{1+\mathrm{Ne}^{2}} \\
& \mathrm{n}=\frac{2.764}{1+2.764 \times(0,05)^{2}} \\
& \mathrm{n}=349,43 \text { dibulatkan menjadi } 350 \text { orang }
\end{aligned}
$$

Keterangan:

$\mathrm{n}=$ Sampel

$\mathrm{N}=$ Populasi

e $=$ Persentase ketidaktelitian karena kesalahan pengambilan sampel yang masih dapat ditolelir. Digunakan tingkat kesalahan 5\%.

\section{Metode Analisis Data}

Metode analisis data dalam penelitian ini dengan bantuan program aplikasi SPSS. Tahapan-tahapan yang dilakukan adalah uji validitas, uji reliabilitas, analisis korelasi dan analisis regresi.

\section{HASIL PENELITIAN DAN PEMBAHASAN}

\section{Uji Validitas}

Hasil uji validitas pada masing-masing variabel (fasilitas akademik, layanan akademik, praktikum, proses akademik dan kepuasan mahasiswa) diperoleh nilai Sig. (2-tailed / 0,000) lebih kecil dari alpha $(\alpha=5 \%$ atau 0,05) dengan tingkat kepercayaan 95\%. Hal tersebut menunjukan bahwa pertanyaan-pertanyaan yang terdapat pada variable-variabel dalam penelitian dinyatakan valid dan dapat digunakan untuk pengolahan data selanjutnya dalam penelitian ini. 


\section{Uji Reliabilitas}

Hasil uji reliabilitas antara masing-masing variabel dapat dilihat pada tabel $1.1 \mathrm{di}$ bawah ini (kolom cronbach's alpha if item deleted) :

Tabel 1.1

Hasil Uji Reliabilitas

\begin{tabular}{|l|l|l|l|l|}
\hline \multirow{2}{*}{ Variables } & $\begin{array}{l}\text { Scale Mean } \\
\text { if } \\
\text { Item } \\
\text { Deleted }\end{array}$ & $\begin{array}{l}\text { Scale } \\
\text { Variance } \\
\text { if Item } \\
\text { Deleted }\end{array}$ & $\begin{array}{l}\text { Corrected } \\
\text { Item- } \\
\text { Total } \\
\text { Correlation }\end{array}$ & $\begin{array}{l}\text { Cronbach's } \\
\text { Alpha if } \\
\text { Item } \\
\text { Deleted }\end{array}$ \\
\hline $\begin{array}{l}\text { Fasilitas_Akademi } \\
\text { k }\end{array}$ & 42.75 & 132.917 & .359 & .922 \\
\hline $\begin{array}{l}\text { Layanan_Akademi } \\
\text { k }\end{array}$ & 49.02 & 141.169 & .346 & .923 \\
\hline Praktikum & 20.85 & 35.009 & .067 & .910 \\
\hline Proses_Akademik & 45.69 & 140.722 & .272 & .958 \\
\hline $\begin{array}{l}\text { Kepuasan_Mahasis } \\
\text { wa }\end{array}$ & 43.97 & 145.966 & 1.000 & .960 \\
\hline
\end{tabular}

Sumber : Hasil Pengolahan Tahun 2017

Berdasarkan data pada tabel tersebut jumlah nilai cronbach's alpha if item deleted variabel fasilitas akademik sebesar 0,922, layanan akademik sebesar 0,923, praktikum sebesar 0,910, proses akademik sebesar 0,958 dan kepuasan mahasiswa sebesar 0,960. Nilainilai tersebut lebih besar dari nilai $\mathrm{r}_{\text {tabel }}=0,68$ untuk $\mathrm{df}=350-2=348$ dengan tingkat signifikansi $5 \%$. Sehinga butir-butir pertanyaan pada masing-masing variabel dinyatakan reliabel dan dapat dipergunakan pada instrumen penelitian berikutnya.

\section{Analisis Korelasi}

a. Hasil analisis korelasi antara fasilitas akademik dengan kepuasan mahasiswa secara parsial terlihat pada tabel 1.2 berikut ini:

Table 1.2 Korelasi antara Fasilitas Akademik dengan Kepuasan Mahasiswa secara Parsial 


\section{Correlations}

\begin{tabular}{|ll|l|l|}
\hline & & $\begin{array}{l}\text { Fasilitas_Ak } \\
\text { ademik }\end{array}$ & $\begin{array}{l}\text { Kepuasan_M } \\
\text { ahasiswa }\end{array}$ \\
\hline Fasilitas_Akademik & Pearson & 1 & $.503^{* *}$ \\
& Sig. (2-tailed) & & .000 \\
& $\mathrm{~N}$ & 194 & 194 \\
& Pearson & $.503^{* *}$ & 1 \\
Kepuasan_Mahasisw & Correlation & & \\
a & Sig. (2-tailed) & .000 & 194 \\
& N & 194 & \\
\hline
\end{tabular}

**. Correlation is significant at the 0.01 level (2-tailed).

Berdasarkan data pada tabel tersebut, nilai korelasi secara parsial antara fasilitas akademik dengan kepuasan mahasiswa sebesar 0,503. Hal ini menunjukan bahwa hubungan secara parsial antara fasilitas akademik dengan kepuasan mahasiswa mempunyai tingkat hubungan sedang dan positif atau searah. Jika fasilitas akademik meningkat maka kepuasan mahasiswa akan naik, demikian sebaliknya.

b. Hasil analisis korelasi antara variabel fasilitas akademik dengan kepuasan mahasiswa dengan variabel kontrol layanan akademik, praktikum dan proses akademik terlihat pada tabel 1.3 berikut ini:

Tabel 1.3 Korelasi antara Fasilitas Akademik dengan Kepuasan Mahasiswa dengan Variabel Kontrol Layanan Akademik, Praktikum dan Proses Akademik

\section{Correlations}

\begin{tabular}{|c|c|c|c|}
\hline Control Variables & & $\begin{array}{l}\text { Fasilitas } \\
\text { - } \\
\text { Akadem } \\
\text { ik }\end{array}$ & $\begin{array}{l}\text { Kepuasan } \\
- \\
\text { Mahasisw } \\
\text { a }\end{array}$ \\
\hline $\begin{array}{l}\text { Layanan_Akademi } \\
\text { k \& } \\
\text { Praktikum \& }\end{array}$ & $\begin{array}{ll}\text { Fasilitas__ } & \text { Correlation } \\
\text { Akademik } & \text { Significance } \\
& \text { tailed) }\end{array}$ & 1.000 & $\begin{array}{l}.072 \\
.322\end{array}$ \\
\hline
\end{tabular}


Analisis Pengaruh Kualitas Pelayanan Terhadap Kepuasan Mahasiswa Universitas Buana Perjuangan Karawang

\begin{tabular}{|lll|l|l|}
\hline Proses_Akademik & & Df & 0 & 189 \\
& Kepuasan & Correlation & .072 & 1.000 \\
& & Significance & $(2-$ & \\
& & & \\
& Mahasisw & tailed $)$ & & \\
& $\mathrm{a}$ & Df & 189 & 0 \\
\hline
\end{tabular}

Berdasarkan data pada tabel tersebut, nilai korelasi antara fasilitas akademik dengan kepuasan mahasiswa dengan variabel kontrol layanan akademik, praktikum dan proses akademik sebesar 0,072. Hal ini menunjukan bahwa hubungan antara fasilitas akademik dengan kepuasan mahasiswa mempunyai tingkat hubungan sangat rendah dan positif atau searah.

c. Hasil analisis korelasi antara layanan akademik dengan kepuasan mahasiswa secara parsial terlihat pada tabel 1.4 berikut ini:

Tabel 1.4 Korelasi antara Variabel Layanan Akademik dengan Kepuasan Mahasiswa secara Parsial

\section{Correlations}

\begin{tabular}{|ll|l|l|}
\hline & & Layanan & Kepuasan \\
& & - & - \\
& & Akadem & Mahasisw \\
ik & $\mathrm{a}$ \\
\hline Layanan_Akademik & Pearson & 1 & $.655^{* *}$ \\
& Sig. (2-tailed) & & .000 \\
& N & 194 & 194 \\
& Pearson & & \\
Kepuasan_Mahasisw & Correlation & $.655^{* *}$ & 1 \\
a & Sig. (2-tailed) & .000 & \\
& N & 194 & 194 \\
\hline
\end{tabular}

**. Correlation is significant at the 0.01 level (2-tailed). 
Berdasarkan data pada tabel tersebut, nilai korelasi secara parsial antara layanan akademik dengan kepuasan mahasiswa sebesar 0,655. Hal ini menunjukan bahwa hubungan secara parsial antara layanan akademik dengan kepuasan mahasiswa mempunyai tingkat hubungan kuat dan positif atau searah. Jika layanan akademik meningkat maka kepuasan mahasiswa akan naik, demikian sebaliknya.

d. Hasil analisis korelasi antara layanan akademik dengan kepuasan mahasiswa dengan variabel kontrol fasilitas akademik, praktikum dan proses akademik terlihat pada tabel 1.5 berikut ini:

Tabel 1.5 Korelasi antara Layanan Akademik dengan Kepuasan Mahasiswa dengan Variabel Kontrol Fasilitas Akademik, Praktikum dan Proses Akademik

\section{Correlations}

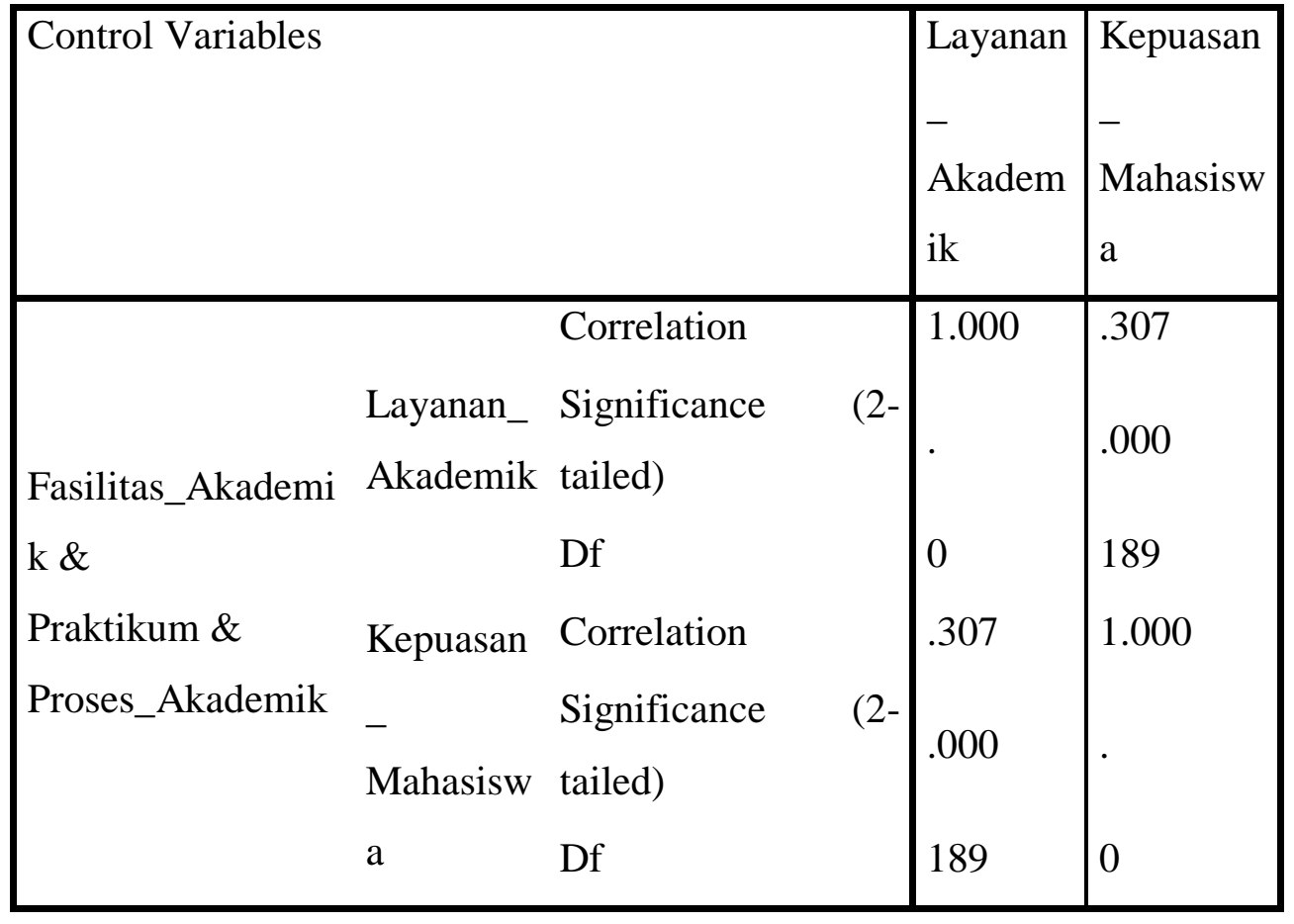

Berdasarkan data pada tabel tersebut, nilai korelasi antara layanan akademik dengan kepuasan mahasiswa dengan variabel kontrol sebesar 0,307. Hal ini menunjukan bahwa hubungan antara layanan akademik dengan kepuasan mahasiswa dengan variabel kontrol fasilitas akademik, praktikum dan proses akademik mempunyai 
tingkat hubungan rendah dan positif atau searah. Jika layanan akademik meningkat maka kepuasan mahasiswa akan naik, demikian sebaliknya.

e. Hasil analisis korelasi antara praktikum dengan kepuasan mahasiswa secara parsial terlihat pada tabel 1.6 berikut ini:

Tabel 1.6 Korelasi anatara Praktikum dengan Kepuasan Mahasiswa secara Parsial

\section{Correlations}

\begin{tabular}{|ll|l|l|}
\hline & & $\begin{array}{l}\text { Praktiku } \\
\mathrm{m}\end{array}$ & $\begin{array}{l}\text { Kepuasan_ } \\
\text { Mahasiswa }\end{array}$ \\
\hline Praktikum & Pearson & 1 & $.625^{* *}$ \\
& Correlation & & .000 \\
& Sig. (2-tailed) & & 194 \\
& $\mathrm{~N}$ & 194 & 1 \\
Kepuasan_Mahasisw & Correlation & $.625^{* *}$ & 1 \\
a & Sig. (2-tailed) & .000 & \\
& N & 194 & 194 \\
\hline
\end{tabular}

**. Correlation is significant at the 0.01 level (2-tailed).

Berdasarkan data pada tabel tersebut, nilai korelasi antara praktikum dengan kepuasan mahasiswa secara parsial sebesar 0,625. Hal ini menunjukan bahwa hubungan secara parsial antara praktikum dengan kepuasan mahasiswa mempunyai tingkat hubungan kuat dan positif atau searah. Jika praktikum baik maka kepuasan mahasiswa akan naik, demikian sebaliknya.

f. Hasil analisis korelasi antara praktikum dengan kepuasan mahasiswa dengan variabel kontrol fasilitas akademik, layanan akademik dan proses akademik terlihat pada tabel 1.7 berikut ini:

Tabel 1.7 Korelasi antara Praktikum dengan Kepuasan Mahasiswa dengan Variabel Kontrol Fasilitas Akademik, Layanan Akademik dan Proses Akademik 


\section{Correlations}

\begin{tabular}{|c|c|c|c|c|}
\hline Control Variables & & & $\begin{array}{l}\text { Praktiku } \\
\mathrm{m}\end{array}$ & $\begin{array}{l}\text { Kepuasan } \\
- \\
\text { Mahasisw } \\
\text { a }\end{array}$ \\
\hline $\begin{array}{l}\text { Fasilitas_Akademi } \\
\text { k \& } \\
\text { Layanan_Akademi } \\
\text { k \& } \\
\text { Proses_Akademik }\end{array}$ & $\begin{array}{l}\text { Kepuasan } \\
- \\
\text { Mahasisw } \\
\text { a }\end{array}$ & $\begin{array}{l}\text { Correlation } \\
\text { Significance } \\
\text { tailed) } \\
\text { Df } \\
\text { Correlation } \\
\text { Significance } \\
\text { tailed) } \\
\text { Df }\end{array}$ & $\begin{array}{l}1.000 \\
. \\
0 \\
.192 \\
.008 \\
189\end{array}$ & $\begin{array}{l}.192 \\
.008 \\
189 \\
1.000\end{array}$ \\
\hline
\end{tabular}

Berdasarkan data pada tabel tersebut, nilai korelasi antara praktikum dengan kepuasan mahasiswa dengan variabel kontrol fasilitas akademik, layanan akademik dan proses akademik sebesar 0,192. Hal ini menunjukan bahwa hubungan antara praktikum dengan kepuasan mahasiswa dengan variabel kontrol fasilitas akademik, layanan akademik dan proses akademik mempunyai tingkat hubungan sangat rendah dan positif atau searah. Jika praktikum baik maka kepuasan mahasiswa akan naik, demikian sebaliknya.

g. Hasil analisis korelasi antara proses akademik dengan kepuasan mahasiswa secara parsial terlihat pada tabel 1.8 berikut ini:

Tabel 1.8 Korelasi antara Proses Akademik dengan Kepuasan Mahasiswa secara Parsial

\section{Correlations}

\begin{tabular}{|ll|l|l|}
\hline & $\begin{array}{l}\text { Proses_ } \\
\text { Akademik }\end{array}$ & $\begin{array}{l}\text { Kepuasan_ } \\
\text { Mahasiswa }\end{array}$ \\
\hline Proses_Akademik & $\begin{array}{l}\text { Pearson } \\
\text { Correlation }\end{array}$ & 1 & $.583^{* *}$ \\
\hline
\end{tabular}


Analisis Pengaruh Kualitas Pelayanan Terhadap Kepuasan Mahasiswa Universitas Buana Perjuangan Karawang

\begin{tabular}{|ll|l|l|}
\hline & Sig. (2-tailed) & & .000 \\
& $\mathrm{~N}$ & 194 & 194 \\
& Pearson & $.583^{* *}$ & 1 \\
Kepuasan_Mahasisw & Correlation & & \\
$\mathrm{a}$ & Sig. (2-tailed) & .000 & \\
& $\mathrm{~N}$ & 194 & 194 \\
\hline
\end{tabular}

**. Correlation is significant at the 0.01 level (2-tailed).

Berdasarkan data pada tabel tersebut, nilai korelasi antara proses akademik dengan kepuasan mahasiswa secara parsial sebesar 0,583. Hal ini menunjukan bahwa hubungan secara parsial antara proses akademik dengan kepuasan mahasiswa mempunyai tingkat hubungan sedang dan positif atau searah. Jika proses akademik baik maka kepuasan mahasiswa akan naik, demikian sebaliknya.

h. Hasil analisis korelasi antara proses akademik dengan kepuasan mahasiswa dengan variabel kontrol fasilitas akademik, layanan akademik dan praktikum terlihat pada tabel 1.9 berikut ini:

Tabel 1.9 Korelasi antara Proses Akademik dengan Kepuasan Mahasiswa dengan Variabel Kontrol Fasilitas Akademik, Layanan Akademik dan Praktikum

\section{Correlations}

\begin{tabular}{|c|c|c|c|c|}
\hline Control Variables & & & $\begin{array}{l}\text { Proses_ } \\
\text { Akadem } \\
\text { ik }\end{array}$ & $\begin{array}{l}\text { Kepuasan } \\
- \\
\text { Mahasisw } \\
\text { a }\end{array}$ \\
\hline Fasilitas_Akademi & & Correlation & 1.000 & .205 \\
\hline $\begin{array}{l}\text { k \& } \\
\text { Layanan_Akademi }\end{array}$ & $\begin{array}{l}\text { Proses_- } \\
\text { Akademik }\end{array}$ & $\begin{array}{l}\text { Significance } \\
\text { tailed) }\end{array}$ & & .005 \\
\hline $\mathrm{k} \&$ & & Df & 0 & 189 \\
\hline Praktikum & Kepuasan & Correlation & .205 & 1.000 \\
\hline
\end{tabular}




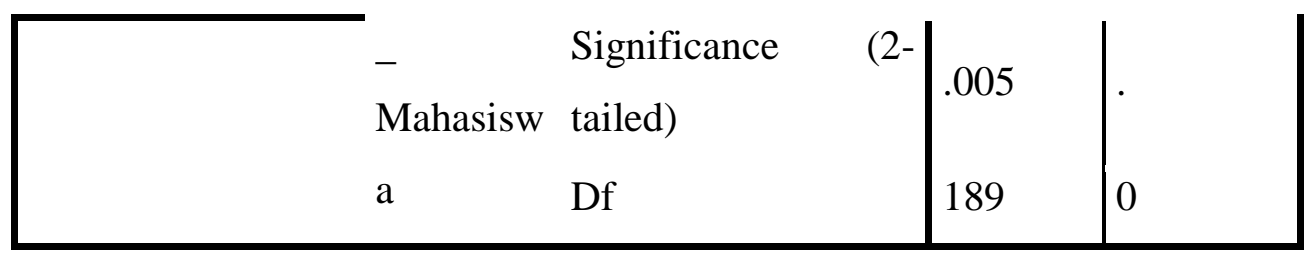

Berdasarkan data pada tabel tersebut, nilai korelasi antara proses akademik dengan kepuasan mahasiswa dengan variabel kontrol fasilitas akademik, layanan akademik dan praktikum sebesar 0,205. Hal ini menunjukan bahwa hubungan antara proses akademik dengan kepuasan mahasiswa dengan variabel kontrol fasilitas akademik, layanan akademik dan praktikum mempunyai tingkat hubungan rendah dan positif atau searah. Jika proses akademik baik maka kepuasan mahasiswa akan naik, demikian sebaliknya.

\section{Analisis Regresi}

Hasil analisis regresi analisis kualitas pelayanan terhadap kepuasan mahasiswa terlihat pada table berikut ini:

Table 1.10 Model Summary

Model Summary

\begin{tabular}{|c|c|c|c|c|c|c|c|c|c|}
\hline \multirow{2}{*}{$\begin{array}{l}\text { Mod } \\
\text { el }\end{array}$} & \multirow[t]{2}{*}{$\mathrm{R}$} & \multirow{2}{*}{$\begin{array}{l}\text { R } \\
\text { Squar } \\
\text { e }\end{array}$} & \multirow{2}{*}{$\begin{array}{l}\text { Adjuste } \\
\text { d } \\
\text { R } \\
\text { Square }\end{array}$} & \multirow{2}{*}{$\begin{array}{l}\text { Std. Error } \\
\text { of } \\
\text { the } \\
\text { Estimate }\end{array}$} & \multicolumn{5}{|c|}{ Change Statistics } \\
\hline & & & & & $\begin{array}{l}\text { R Square } \\
\text { Change }\end{array}$ & $\begin{array}{l}\mathrm{F} \\
\text { Chang } \\
\mathrm{e}\end{array}$ & df1 & $\mathrm{df} 2$ & $\begin{array}{l}\text { Sig. } \\
\text { F } \\
\text { Change }\end{array}$ \\
\hline 1 & $\begin{array}{l}.724 \\
\mathrm{a}\end{array}$ & .524 & .514 & 8.599 & .524 & 52.040 & 4 & 189 & .000 \\
\hline
\end{tabular}

a. Predictors: (Constant), Proses_Akademik, Fasilitas_Akademik, Praktikum, Layanan_Akademik

Berdasarkan data pada tabel tersebut diperoleh nilai koefisien korelasi (R) sebesar 0,724 atau $\mathrm{R}>0$, artinya bahwa terdapat hubungan kuat $(0,600-0,799=$ kuat $)$ antara kualitas pelayanan (fasilitas akademik, layanan akademik, praktikum dan proses akademik) dengan kepuasan mahasiswa. Nilai koefisien determinasi (R Square atau $\mathrm{R}^{2}$ ) sebesar 0,524 atau $52,40 \%$, Nilai tersebut menunjukan kemampuan variabel kualitas pelayanan (fasilitas akademik, layanan akademik, praktikum dan proses akademik) menjelaskan variansi pada 
Analisis Pengaruh Kualitas Pelayanan Terhadap Kepuasan Mahasiswa Universitas Buana Perjuangan Karawang

variabel kepuasan mahasiswa sebesar 52,40\% dan sisanya sebesar 47,60\% dipengaruhi oleh faktor lain (e) yang tidak diikutsertakan dalam penelitian ini. Faktor lain tersebut seperti komunikasi, budaya organisasi, prestasi akademik dan lain-lain.

Tabel 1.11 Model Anova

\section{ANOVA $^{\mathrm{a}}$}

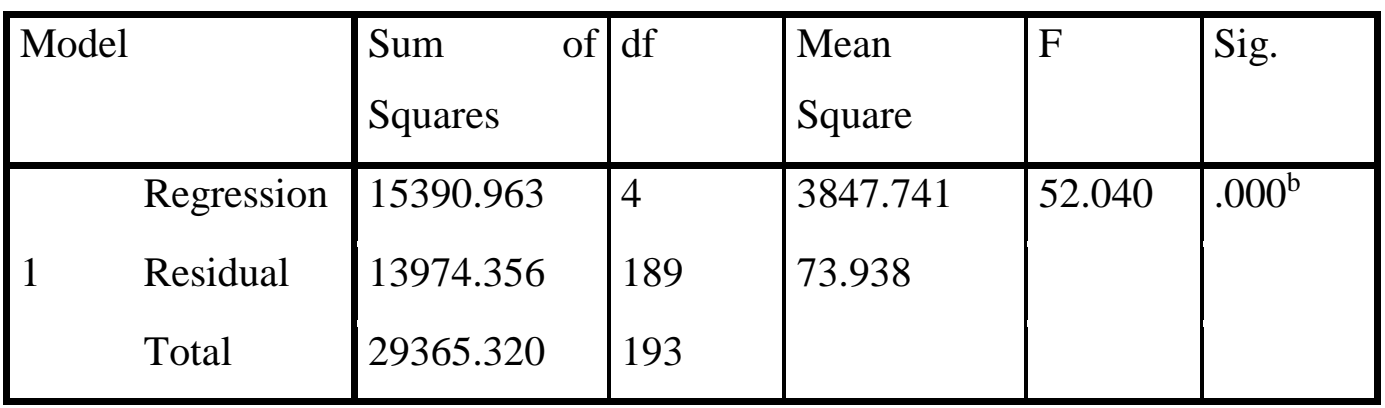

a. Dependent Variable: Kepuasan_Mahasiswa

b. Predictors: (Constant), Proses_Akademik, Fasilitas_Akademik, Praktikum, Layanan_Akademik

Berdasarkan data pada tabel tersebut diperoleh nilai signifikansi $\mathrm{F}$ sebesar 0,000 (Pvalue) artinya bahwa kualitas pelayanan (fasilitas akademik, layanan akademik, praktikum dan proses akademik) berpengaruh signifikan terhadap kepuasan mahasiswa. Atau dengan memperhatikan nilai $F_{\text {hitung }}(52,040)$ yang mempunyai nilai lebih besar dari nilai $F_{\text {tabel }}(2,42)$ atau 52,040> 2,42 yang berarti bahwa kualitas pelayanan (fasilitas akademik, layanan akademik, praktikum dan proses akademik) berpengaruh terhadap kepuasan mahasiswa.

Tabel 1.12 Model Coefficients

\section{Coefficients $^{\mathrm{a}}$}

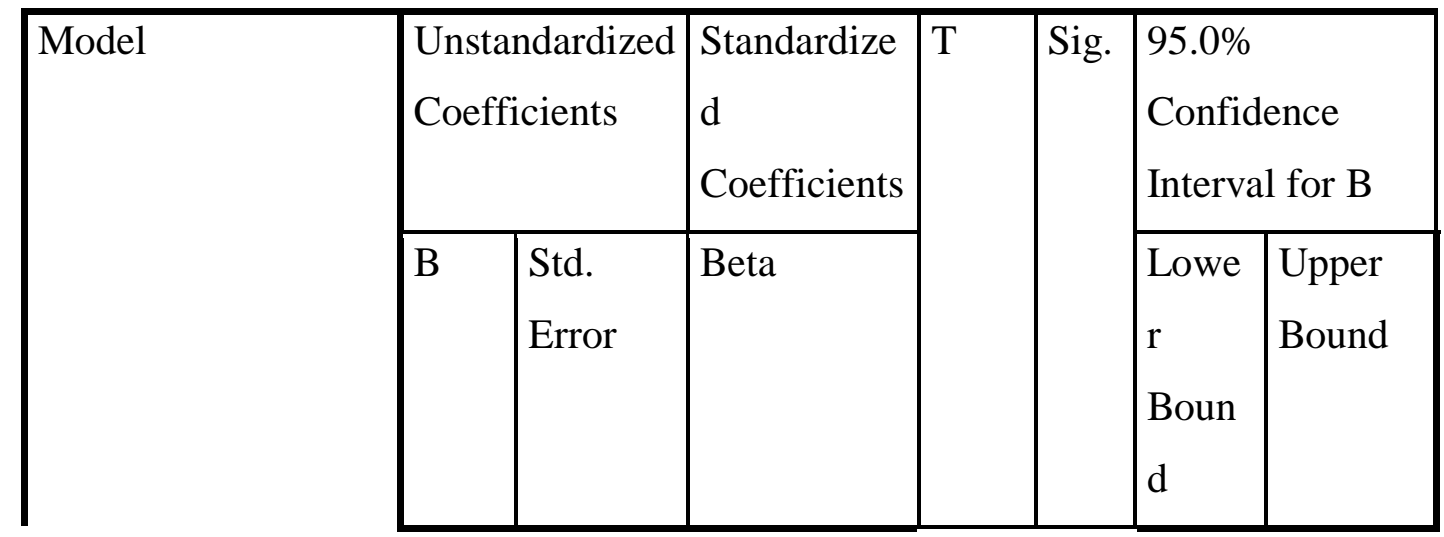




\begin{tabular}{|c|c|c|c|c|c|c|c|}
\hline (Constant) & $\begin{array}{l}3.91 \\
3\end{array}$ & 2.967 & & $\begin{array}{l}1.31 \\
9\end{array}$ & .189 & $\begin{array}{l}- \\
1.940\end{array}$ & 9.766 \\
\hline $\begin{array}{l}\text { Fasilitas_Akade } \\
\text { mik }\end{array}$ & .075 & .076 & .070 & .993 & .322 & -.074 & .224 \\
\hline $\begin{array}{l}\text { Layanan_Akade } \\
\text { mik }\end{array}$ & .362 & .081 & .356 & $\begin{array}{l}4.44 \\
1\end{array}$ & .000 & .201 & .522 \\
\hline Praktikum & .439 & .164 & .214 & $\begin{array}{l}2.68 \\
4\end{array}$ & .008 & .116 & .762 \\
\hline $\begin{array}{l}\text { Proses_Akademi } \\
\mathrm{k}\end{array}$ & .218 & .076 & .210 & $\begin{array}{l}2.87 \\
3\end{array}$ & .005 & .068 & .368 \\
\hline
\end{tabular}

a. Dependent Variable: Kepuasan_Mahasiswa

Berdasarkan data pada tabel di atas diperoleh persamaan regresi linear sebagai berikut :

$$
\mathrm{Y}=3,913+0,075 \mathrm{X}_{1}+0,362 \mathrm{X}_{2}+0,439 \mathrm{X}_{3}+0,218 \mathrm{X}_{4}+\mathrm{e}
$$

Dari persamaan regresi linier tersebut dapat dideskripsikan sebagai berikut:

a. Nilai koefisien sebesar 3,913 adalah nilai koefisien kepuasan mahasiswa (Y) saat kualitas pelayanan (fasilitas akademik/ $\mathrm{X}_{1}$, layanan akademik/ $\mathrm{X}_{2}$, praktikum/ $\mathrm{X}_{3}$ dan proses akademik/ $\mathrm{X}_{4}$ ) sama dengan nol (0).

b. Nilai sebesar 0,075 pada koefisien $\mathrm{X}_{1}$ yaitu jika fasilitas akademik $\left(\mathrm{X}_{1}\right)$ naik sebesar 1 satuan unit skor, maka kepuasan mahasiswa (Y) akan naik sebesar 3,913 dan variabel lain (layanan akademik/ $\mathrm{X}_{2}$, praktikum/ $\mathrm{X}_{3}$ dan proses akademik/ $\mathrm{X}_{4}$ ) dianggap tetap.

c. Nilai sebesar 0,362 pada koefisien $\mathrm{X}_{2}$ yaitu jika layanan akademik $\left(\mathrm{X}_{2}\right)$ naik sebesar 1 satuan unit skor, maka kepuasan mahasiswa (Y) akan naik sebesar 0,362 dan variabel lain (fasilitas akademik/ $\mathrm{X}_{1}$, praktikum/ $\mathrm{X}_{3}$ dan proses akademik/ $\mathrm{X}_{4}$ ) dianggap tetap.

d. Nilai sebesar 0,439 pada koefisien $\mathrm{X}_{3}$ yaitu jika praktikum $\left(\mathrm{X}_{3}\right)$ naik sebesar 1 satuan unit skor, maka kepuasan mahasiswa (Y) akan naik sebesar 0,439 dan variabel lain (fasilitas akademik/ $\mathrm{X}_{1}$, layanan/ $\mathrm{X}_{2}$ dan proses akademik/ $\mathrm{X}_{4}$ ) dianggap tetap.

e. Nilai sebesar 0,218 pada koefisien $\mathrm{X}_{4}$ yaitu jika proses akademik $\left(\mathrm{X}_{4}\right)$ naik sebesar 1 satuan unit skor, maka kepuasan mahasiswa (Y) akan naik sebesar 0,218 dan variabel lain (fasilitas akademik/ $\mathrm{X}_{1}$, layanan akademik/ $\mathrm{X}_{2}$ dan praktikum/ $\mathrm{X}_{3}$ ) dianggap tetap. 


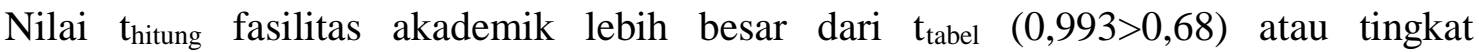
signifikansi $t_{\text {hitung }}$ lebih kecil dari nilai alpha $(0,000<0,05)$, dengan demikian bahwa terjadi penolakan $\mathrm{H}_{0}$ atau penerimaan $\mathrm{H}_{\mathrm{a} 1}$ yang berarti menunjukan adanya pengaruh fasilitas akademik $\left(\mathrm{X}_{1}\right)$ secara signifikan terhadap kepuasan mahasiswa $(\mathrm{Y})$.

Nilai $t_{\text {hitung }}$ layanan akademik lebih besar dari $t_{\text {tabel }}(4,441>0,68)$ atau tingkat signifikansi thitung lebih kecil dari nilai alpha $(0,000<0,05)$, dengan demikian bahwa terjadi penolakan $\mathrm{H}_{0}$ atau penerimaan $\mathrm{H}_{\mathrm{a}}$ yang berarti menunjukan adanya pengaruh layanan akademik $\left(\mathrm{X}_{2}\right)$ secara signifikan terhadap kepuasan mahasiswa $(\mathrm{Y})$.

Nilai $t_{\text {hitung }}$ praktikum lebih besar dari $t_{\text {tabel }}(2,684>0,68)$ atau tingkat signifikansi $t_{\text {hitung }}$ lebih kecil dari nilai alpha $(0,000<0,05)$, dengan demikian bahwa terjadi penolakan $\mathrm{H}_{0}$ atau penerimaan $\mathrm{H}_{\mathrm{a}}$ yang berarti menunjukan adanya pengaruh praktikum $\left(\mathrm{X}_{3}\right)$ secara signifikan terhadap kepuasan mahasiswa (Y).

Nilai $t_{\text {hitung }}$ proses akademik lebih besar dari $t_{\text {tabel }}(2,873>0,68)$ atau tingkat signifikansi $t_{\text {thitung }}$ lebih kecil dari nilai alpha $(0,000<0,05)$, dengan demikian bahwa terjadi penolakan $\mathrm{H}_{0}$ atau penerimaan $\mathrm{H}_{\mathrm{a} 1}$ yang berarti menunjukan adanya pengaruh proses akademik $\left(\mathrm{X}_{4}\right)$ secara signifikan terhadap kepuasan mahasiswa (Y).

\section{KESIMPULAN}

Berdasarkan hasil penelitian dan pembahasan, maka dapat diambil kesimpulan sebagai berikut:

1. Terdapat pengaruh fasilitas akademik $\left(\mathrm{X}_{1}\right)$ secara signifikan terhadap kepuasan mahasiswa (Y).

2. Terdapat pengaruh layanan akademik $\left(\mathrm{X}_{2}\right)$ secara signifikan terhadap kepuasan mahasiswa (Y).

3. Terdapat pengaruh praktikum $\left(\mathrm{X}_{3}\right)$ secara signifikan terhadap kepuasan mahasiswa $(\mathrm{Y})$.

4. Terdapat pengaruh proses akademik $\left(\mathrm{X}_{4}\right)$ secara signifikan terhadap kepuasan mahasiswa $(\mathrm{Y})$.

\section{E. SARAN}

Saran-saran yang dapat peneliti berikan berdasarkan hasil penelitian dan analisis data adalah:

1. Untuk meningkatkan fasilitas akademik, hal-hal yang harus diperbaiki yaitu berkaitan dengan ketersediaan fasilitas olah raga, ketersediaan taman / hall / ruang publik dan ketersediaan air dan kebersihan pada kamar mandi / toilet. 
2. Untuk meningkatkan layanan akademik, hal-hal yang harus diperhatikan adalah ketersediaan informasi tentang lowongan kerja / magang, kemudahan dalam mendapatkan beasiswa dan informasi tentang beasiswa.

3. Untuk meningkatkan praktikum

4. Untuk meningkatkan proses akademik, hal-hal yang harus diperbaiki yaitu kesempatan berdiskusi atau bertanya dalam perkuliahan, kejelasan tujuan pembelajaran setiap mata kuliah dan alokasi waktu mengajar dosen sesuai alokasi waktu yang ditetapkan.

\section{F. DAFTAR PUSTAKA}

Fandy Tjiptono, Gregorius Chandra, Dadi Adriana, 2007. Pemasaran Strategik. ANDY, Yogyakarta.

Fandy Tjiptono, 2004. Pemasaran Jasa. Edisi Ketiga. Bayumedia Publishing, Malang Jawa Timur.

Indriantoro, Nur, dan Bambang Supomo. 1999. Metodologi Penelitian Bisnis. BPFE. Yogyakarta.

Lupiyoadi, Rambat, 2001. Manajemen Pemasaran Jasa Teori dan Praktek, Edisi pertama, Yogyakarta : Andy Offset.

Parasuraman, A., Zeithaml, V. A., \& Berry, L. L. 1985. A Conceptual Model of Service Quality and Its Implications for Future Research. Journal of Marketing, Vol.49, 4150 .

Parasuraman, A., Zeithaml, V. A., \& Berry, L. 1988. SERVQUAL: A Multiple-Item Scale for Measuring Consumer Perceptions of Service Quality. Journal of Retailing, Vol.64 No. 1, 12-40.

Philips Kotler, 2002. Manajemen Pemasaran, Edisi Mellenium Jilid 1. By Pearson Education asia Pte. Ltd dan PT. Prenhallindo, Jakarta.

Siswoyo Haryono. 2004. Metode Penelitian Bisnis. Badan Penerbit MM UTP, Palembang. Siswoyo Haryono. 2007. Metode Penelitian Bisnis. Badan Penerbit MM UTP, Edisi Kedua, Palembang.

Siswoyo Haryono. 2007. Statistika Penelitian Manajemen. Program Pascasarjana Magister Manajemen, UTP Palembang.

Sugiyono, 2002. Statistika untuk Penelitian. CV. Alfabeta, Bandung.

Sugiyono. 2001. Metode Penelitian Bisnis. CV. Alfabeta. Bandung

Sugiyono, 1999. Metode Bisnis. CV. Alfabeta, Bandung. 